\title{
Rigsfællesskabet i multilateralt arktisk forskningssamarbejde
}

Af Rasmus Gjedssø Bertelsen og Morten Rasch

Globalisering og magtforskydning kommer til udtryk overalt i det internationale system, også i Arktis og hermed i arktisk videnskab. Kina, Indien, Japan, Singapore og Sydkorea har opnået observatørstatus i Arktisk Råd, og disse vækstøkonomier har klimavidenskabelige interesser, søger energi og råstoffer globalt og ser sig selv som naturlige deltagere i regional governance forskellige steder $i$ verden inklusive Arktis. Det er baggrundstæppet for Kongeriget Danmarks og de øvrige nordiske arktiske småstaters - deltagelse i multilateralt arktisk forskningssamarbejde.

Kongeriget Danmark og de øvrige nordiske lande er typiske småstater i international politik - også i Arktis over for supermagten USA, stormagten Rusland og mellemmagten Canada. Derudover er en række europæiske og asiatiske stormag- ter interesserede i Arktis som del af deres globale engagement. De nordiske landes status som småstater er tydelig ud fra især befolkningstal. Småstater påvirkes langt mere af det internationale system og større stater end omvendt, men de kan forfølge multilaterale strategier for at påvirke normer og institutioner. Det er også tilfældet for de nordiske lande i Arktis.

Småstaten Danmark har i århundreder været under betydeligt pres fra større stater og europæisk og global magtpolitik også i Arktis. Under Første og Anden verdenskrig var Danmark igen under ekstremt pres af europæisk magtpolitik med tab af kontakt til Nordatlanten og britisk og amerikansk beskyttelse af Island, Færøerne og Grønland med vidtrækkende politiske, økonomiske og samfundsmæssige konsekvenser.

De to supermagter dominerede Arktis under den kolde krig. Den kolde krigs

Rasmus Gjedssø Bertelsen er professor i Nordområdestudier og 'Barents Chair in Politics' ved Universitetet i Tromsø og seniorforsker ved Aalborg Universitet.

Morten Rasch er chefkonsulent og arktisk koordinator ved Institut for Geovidenskab og Naturforvaltning ved Københavns Universitet. Han har en fortid som forsker. 
De to supermagter dominerede Arktis under den kolde krig. Den kolde krigs ophør påvirkede i udstrakt grad Arktis og tillod samarbejde rundt om polen - dvs. også med sovjetisk deltagelse - inden for bl.a. videnskab, civilsamfund, oprindelige folk, miljøbeskyttelse og eftersøgning og redning.

ophør påvirkede i udstrakt grad Arktis og tillod samarbejde rundt om polen dvs. også med sovjetisk deltagelse inden for bl.a. videnskab, civilsamfund, oprindelige folk, miljøbeskyttelse og eftersøgning og redning. Finland greb bolden fra Mikhail Gorbatjovs berømte Murmansk-tale fra 1987 og indledte Rovaniemi-processen, som førte til 'Arctic Environmental Protection Strategy' i 1991. Norge tog initiativet til en meget aktiv nordområdepolitik i sin Barentsregion, som førte til Barents Euro Arctic Council i 1993. Mellemmagten Canada spillede den finske bold videre og tog initiativet til Arktisk Råd i 1996.

Arktis har i århundreder været genstand for europæiske magters politiske, $ø$ konomiske, militære og videnskabelige interesse, hvad enten det var i jagten på nye søveje til Asien, baskisk og bretonsk langdistancefiskeri i Nordatlanten, hollandske 1600-tals hvalfangere ved Svalbard eller kampen om Murmanskkonvojerne. Storbritannien, Holland, Spanien, Tyskland, Polen og Frankrig har derfor været observatører i Arktisk Råd siden sidst i 1990'erne. Men i de seneste ca. 10 år har interessen for Arktis spredt sig videre til især de asiatiske vækstøkonomier anført af Kina, hvilket har vakt stor interesse og til dels kontrovers i Arktis.

Denne nye interesse for Arktis afspejler miljømæssig og samfundsmæssig globalisering. Med miljømæssig globalisering mener vi først og fremmest klimaændringer i Arktis, som fx også påvirker Kina. Samfundsmæssig globalisering er her magtforskydningen ved den fænomenale økonomiske vækst, som især Kina har præsteret siden åbningen af landet i 1978. Kongeriget Danmark og Norden påvirkes dybt af denne globalisering og må forholde sig til den på en lang række samfundsområder, inklusive som arktiske stater.

Globalisering og magtforskydning kommer til udtryk overalt i det internationale system, også i Arktis - herunder i arktisk videnskab, illustreret ved at Kina, Indien, Japan, Singapore og Sydkorea har opnået observatørstatus i Arktisk Råd fra maj 2013. Vi ser, hvordan disse vækstøkonomier har klimavidenskabelige interesser, søger energi og råstoffer globalt (hvor Arktis er én mulig kilde blandt mange), ser sig selv som naturlige deltagere i regional governance forskellige steder i verden, inklusive i Arktis og satser på hastig udvikling af deres videnskab og undervisningssektorer i takt med deres økonomiske vækst.

Det er baggrundstæppet for Kongeriget Danmarks - og de øvrige nordiske arktiske småstaters - deltagelse i multilateralt arktisk forskningssamarbejde. Men lad os først minde os selv om, at Arktis er stort.

\section{Det enorme Arktis}

Arktis er en arealmæssigt enorm region. Der findes forskellige definitioner af Arktis afhængig af geografi, klima, etc., men $i$ en samfundsmæssig kontekst er den mest anvendelige definition givet i Arctic Human Development Report, som inklu- 
derer enorme områder i Rusland, det nordlige Fenno-Skandia med Lapland i Finland, Norrbotten og Västerbotten i Sverige, Finnmark, Nordland og Troms i Norge, Island, Færøerne, Grønland, enorme områder i Canada og hele staten Alaska samt naturligvis havområderne der omkring.

Den nærmeste subregion for Kongeriget Danmark er Vestnorden, som består af Grønland, Island, Færøerne og i nogle sammenhænge Kystnorge. Vi har Vestnordisk Råd med parlamentarikere fra Grønland, Island og Færøerne. Vi har også NORA, Nordatlantisk samarbejde under Nordisk Ministerråd, som støtter samfundsudvikling inden for erhverv, uddannelse, etc. i Vestnorden og Kystnorge.

En uhyre vigtig region for Europas engagement i Arktis, som desværre langt fra får tilstrækkelig opmærksomhed fra Vestnorden og Danmark, er Barents Euro Arctic Region (BEAR). BEAR er både et mellemstatsligt samarbejde i Barents Euro Arctic Council mellem de nordiske lande, Rusland, og EU og et territorielt samarbejde mellem regionale myndigheder i Nordvest-Rusland, det nordlige Finland, Sverige og Norge. Som dansk professor i Tromsø bemærker man ressource- og aktivitetsniveauet $\mathrm{i}$ Barentsregionen. Befolkningstal og økonomi her er naturligvis langt større end i Vestnorden, hvilket fx kommer til udtryk i en række centrale universiteter og institutter for arktisk forskning i Petrozavodsk, Arkhangelsk, Murmansk, Rovaniemi, Oulu, Luleå, Umeå, Tromsø og Bodø samt mindre byer. Nordisk Ministerråds arktiske programmer samler både Vestnorden og Barentsregionen, men vores erfaring er, at der ikke er tilstrækkelig gensidig indsigt og erfaring mellem Vestnorden og Barentsregionen.

En tredje region langt væk fra Kongeriget Danmark - men med historiske bånd til Danmark - er Beringregionen mellem Alaska og det russiske Fjernøsten, der er opkaldt efter den danske søofficer i Peter den Stores tjeneste, Vitus Bering (1681-1741). Denne 'zarens Columbus' lagde grunden til det russiske Amerika, Alaska, som ved salget i 1867 gjorde USA til en arktisk stat. USA og USSR/Rusland samarbejder nært omkring fiskeriforvaltning og andre spørgsmål i Beringregionen, som er et af verdens rigeste fiskeområder. Alaska er en USA's vigtigste olieproducerende stater og arealmæssigt langt den største stat.

\section{Multilateralt arktisk forsknings- samarbejde}

Arktis er en enorm region befolket af otte stater, lokalbefolkninger og oprindelige befolkninger. Desuden har en række større europæiske lande i århundreder været engageret politisk, økonomisk, militært og videnskabeligt i regionen, og de har i de seneste år fået følgeskab af globaliseringens asiatiske vækstøkonomier. Det udstrakte forskningssamarbejde i Arktis er derfor primært organiseret i en række multilaterale institutioner og fora, hvor vi her vil introducere de vigtigste: International Arctic Science Committee, International Arctic Social Sciences Association, European Polarboard, University of the Arctic, arbejdsgrupperne under Arktisk Råd og afslutningsvis China Nordic Arctic Research Center.

Dette multilaterale arktiske forskningssamarbejde er den afgørende ramme for vidensbaseret samtale i Arktis og om 
Arktis' fremtid, hvor regionens fremtid i høj grad formes.

Den overordnede internationale organisation for arktisk forskningssamarbejde er International Arctic Science Committee (IASC). IASC er stiftet af videnskabelige organisationer i de otte arktiske stater i 1990 netop som et resultat af nye muligheder ved den kolde krigs ophør. IASC har i dag i alt 23 medlemslande, hvoraf de 15 ligger uden for det arktiske område. IASC har observatørstatus i forhold til Arktisk Råd og faciliterer forskningssamarbejde på tværs af det arktiske område blandt andet via årlige møder i Arctic Science Summit Week. IASC driver en lang række faglige arbejdsgrupper, som blandt andet udarbejder internationale rapporter og forskningsstrategier.

Arbejdet i IASC har til tider haft implikationer langt ud over forskerverdenen. IASC tog således initiativ til udarbejdelsen af Arctic Climate Impact Assesment, som blev præsenteret i 2004, fik stor politisk opmærksomhed og førte til øget internationalt samarbejde omkring reduktion af klimaforandringerne.

Tilsvarende blev International Arctic Social Sciences Association (IASSA) grundlagt i 1990 i forlængelse af et forslag om at stifte en forening af arktiske samfundsforskere ved Conference on the Coordination of Research in the Arctic i Leningrad i 1988. IASSA afholder kongres hvert tredje år ved et arktisk eller nordligt universitet. Både Institut for Eskimologi ved Københavns Universitet og Ilisimatusarfik - Grønlands Universitet har huset IASSAs sekretariat. Umeå Universitet huser pt. sekretariatet.

EU har de seneste år satset mere og mere på koordineret at synliggøre sin tilstedeværelse i både Arktis og Antarktis.
Dette gøres blandt andet via European Polar Board (EPB), som har medlemmer fra i alt 17 europæiske lande. Fokus er på det forskningsmæssige, men det er samtidig udtalt meget tydeligt, at EPB beskæftiger sig med strategiske prioriteter i Arktis og Antarktis.

EPB arbejder tæt sammen med projektet EU-PolarNet, som blandt andet har til formel at synliggøre den europæiske tilstedeværelse i den arktiske og antarktiske forskning og herunder den omfattende forskningsinfrastruktur. Forskningens platforme bliver et middel til at markere EU's tilstedeværelse i Arktis og EU's prioritering af det arktiske og det antarktiske område.

Arktiske universiteter og andre organisationer interesserede i Arktis samarbejder indgående inden for netværksorganisationen University of the Arctic (UArctic). UArctic udsprang fra den tidligere Circumpolar Universities Association i 2002. UArctic er organiseret med en rektor, norske Lars Kullerud, og vice-rektorer i Fairbanks, Rovaniemi, Oulu, Arkhangelsk og Newfoundland. UArctic har ca. 170 medlemsorganisationer, heraf følgende fra Rigsfællesskabet: Aarhus Universitet, Aalborg Universitet, Syddansk Universitet, Københavns Universitet, Danmarks Tekniske Universitet og Copenhagen Business School, Roskilde Universitet, Nordisk Fond for Miljø og Udvikling, Færøernes Universitet, Ilisimatusarfik - Grønlands Universitet, Grønlands Naturinstitut og Grønlands uddannelser for Socialhjælpere, Socialassistenter og Professionsrettede bachelorer i Socialpædagogik. UArctic arbejder især gennem tematiske netværk af forskere fra forskellige lande. Der er 32 tematiske netværk inden for humaniora, natur- 
og samfundsvidenskab, teknologi og sundhedsvidenskab. Derudover er der udstrakt undervisningssamarbejde og studenterudveksling inden for UArctic.

Arktisk Råd er et mellemstatsligt forum mellem de otte arktiske stater og seks oprindelige folk. Derudover er en række lande og organisationer observatører. Formandskabet går på omgang mellem medlemsstaterne, og der holdes ministermøde hvert andet år. Indimellem ledes rådet af medlemsstaternes Senior Arctic Officials. Rådet fungerer ved konsensus og er 'beslutningsskabende' i stedet for 'beslutningstagende'. Rådets arbejde foregår i seks arbejdsgrupper af eksperter fra medlemsstater, oprindelige folk og observatører inden for miljøbeskyttelse og bæredygtig udvikling. Nogle af disse permanente arbejdsgrupper går tilbage til det finske initiativ om Arctic Environmental Protection Strategy i 1991 og er centrale transnationale vidensfællesskaber.

Af særlig relevans for forskerverdenen er arbejdsgrupperme Arctic Monitoring and Assesment Programme (AMAP), som arbejder med grænseoverskridende forurening og klimaændringer, samt Conservation of Arctic Flora and Fauna (CAFF), som arbejder med bevarelse af biodiversitet. Begge disse arbejdsgrupper støttes massivt fra dansk side via tocifrede millionbevillinger fra Miljøstyrelsen og Energistyrelsen.

Arktis - og Kongeriget Danmark - påvirkes som resten af verden af magtforskydning og globalisering, hvor især Kinas genfundne interesse for Arktis får meget opmærksomhed (vi skriver 'genfundne', fordi Kina allerede i 1925 tilsluttede sig Svalbard/Spitsbergen-traktaten fra 1920).
I 2013 grundlagde en række nordiske og kinesiske institutioner China-Nordic Arctic Research Center (CNARC) ved Polar Research Institute of China (PRIC) i Shanghai på kinesisk-islandsk initiativ. Kina og Island valgte at fokusere deres forskningssamarbejde på arktisk forskning og at udvide dette samarbejde til et nordisk-kinesisk samarbejde. Medlemsinstitutioner er i Norden: The Icelandic Centre for Research RANNÍS, Norsk Polarinstitutt, Fridtjof Nansens Institutt, Polarforskningssekretariatet (Sverige), Arctic Centre (University of Lapland, Finland) og Nordisk Institut for Asienstudier (Københavns Universitet). I Kina er det: PRIC, Ocean University of China, Shanghai Institutes for International Studies, Tongji University og Shanghai Jiao Tong University. CNARC afholder hvert år ChinaNordic Arctic Cooperation Symposium (CNACS). CNARC organiserer og finansierer også udveksling af gæsteforskere mellem Shanghai og Norden. CNARC og CNACS er den ubestridte ramme for nordisk-kinesisk samfundsvidenskabelig dialog og samarbejde om Arktis' politiske og økonomiske udvikling.

\section{Vejen frem}

Som typiske småstater har Kongeriget Danmark og de øvrige nordiske lande en grundlæggende interesse i multilateralt samarbejde, institutioner og normer. Multilateralt samarbejde giver småstater adgang til ressourcer, som de ikke selv råder over. Det styrker småstater at optræde sammen i multilaterale organisationer, som endvidere skaber institutioner og normer, som tæmmer større stater. Ved at deltage i tidlige faser og på langt sigt i multilateralt samarbejde kan småstater sikre sig adgang til information 
og indflydelse. Det er også tilfældet i arktisk forskningssamarbejde.

Arktis er en enorm region og en meget kostbar region at forske i. Derfor kan danske, færøske og grønlandske forskere og studerende bedst få adgang til viden og ressourcer til at forsøge at forstå arktisk natur og samfund i sin helhed gennem multilateralt forskningssamarbejde. Disse organisationer og fora for arktisk forskningssamarbejde er samtidig de mest effektive rammer for udenlandske forskere og studerende til at få adgang til dansk, færøsk og grønlandsk forskning samt til Færøerne og Grønland.

Det er af stor betydning, at man i Kongeriget Danmark er meget bevidst om, at Arktis er en enorm circumpolar region, der både har distinkte subregioner og udgør et hele. Blandt de arktiske stater er supermagten USA, stormagten Rusland, som udgør halvdelen af Arktis, hvilket gør arktisk samtale eller aktivitet uden russisk deltagelse meningsløs, mellemmagten Canada og de fem nordiske småstater.

Uden for Arktis har en række europæiske lande århundreders interesser i Arktis, som nu følges op på EU-niveau. Globaliseringen bringer de asiatiske vækst$ø$ konomier indenfor.

Under disse forudsætninger er det klart, at dansk, færøsk og grønlandsk arktisk forskning i høj grad må forankres i de her nævnte multilaterale forskningsorganisationer og fora. Derved sikres alle dele af Rigsfællesskabet adgang til og indflydelse på international arktisk forskning, hvor Arktis' fremtid i høj grad formes. 
